\section{Cultural and Environmental Factors Governing Tomato Production: Local Production under Elevated Temperatures}

\author{
John L. Snider ${ }^{3}$ \\ Department of Crop and Soil Sciences, University of Georgia, 115 Coastal \\ Way, Tifton, GA 31794
}

\section{Vincent M. Russo}

USDA, Agricultural Research Service, Wes Watkins Agricultural Research Laboratory, 911 East Highway 3, Lane, OK 74555

\section{Warren Roberts \\ Oklahoma State University, Wes Watkins Agricultural Research and Extension Center, 911 East Highway 3, Lane, OK 74555}

\section{Elbert V. Wann'}

USDA, Agricultural Research Service, Wes Watkins Agricultural Research Laboratory, 911 East Highway 3, Lane, OK 74555

\author{
Randy L. Raper ${ }^{2}$ \\ USDA, Agricultural Research Service, Dale Bumpers Small Farms Research \\ Center, 6883 South State Highway 23, Booneville, AR 72927
}

Additional index words. Solanum lycopersicum, tomato, local foods, climate change, heat units, marketable yield

\begin{abstract}
Long-term fresh tomato (Solanum lycopersicum L.) production data were used to estimate cultural and environmental impacts on marketable tomato yields in eastern Oklahoma. Quantifying the interactive effects of planting date and growing season duration and the effects of cumulative heat units and heat unit accumulation rate on marketable yields allowed for productivity estimates based on past temperature conditions. Simulated increases in air temperature were predicted to reduce yields and increase the amount of cropland needed to meet local consumption demands. Consequently, local tomato production in Oklahoma may be negatively impacted under elevated temperature conditions projected under global climate change.
\end{abstract}

There has been increased interest in local food production throughout the United States (Duram and Oberholtzer, 2010; Lapping, 2004; Lyson and Guptill, 2004; Timmons et al., 2008). Despite limited quantitative studies, some positive attributes associated with local food production include reduced greenhouse gas emissions (Jones, 2002), decreased energy

Received for publication 12 Apr. 2012. Accepted for publication 22 May 2012.

We thank Tim Abney, Ron Marble, and Wyatt O'Hern for their support with this project.

Mention of trade names or commercial products in this publication is solely for the purpose of providing specific information and does not imply recommendation or endorsement by the U.S. Department of Agriculture. USDA is an equal opportunity provider and employer.

${ }^{1}$ Retired.

${ }^{2}$ Present address: Field and Research Services Unit, Oklahoma State University, 139 Agricultural Hall, Stillwater, OK 74078.

${ }^{3}$ To whom reprint requests should be addressed; e-mail jlsnider@uga.edu. selection, cultural practices, and environmental constraints (Ortiz et al., 2007). In multienvironment trials with tomato, Ortiz et al. (2007) reported substantial variation among 15 genotypes in their marketable yield and fruit size responses to climatic factors, soil conditions, and cultural practices. Consequently, selecting an ideal cultivar for production within a given region and using well-established best management practices (McGraw et al., 2007) are essential for achieving acceptable levels of productivity.

Apart from proper cultivar selection and use of well-established cultural practices for fresh tomato production (McGraw et al., 2007), the environment encountered during plant development will strongly influence yield. Plant development is strongly linked to temperature (Reeves and Coupland, 2000), and the heat unit (HU) approach (accumulation of average daily temperatures above a base temperature during the growing season) has been used as a means to estimate timing of key events in vegetative and reproductive development of many different plant species (Gilmore and Rogers, 1958; Orlandi et al., 2005; Peng et al., 1989; Perry et al., 1997; Wang, 1960). Heat unit accumulation during the growing season has been used to estimate optimal harvest times in tomato (Perry et al., 1997), and the summation of HUs required for crop maturity has been widely regarded as a varietal constant by many investigators [reviewed in Wang (1960)].

An important critique of the HU approach is that periods of extreme high temperature are often masked when HUs are summed for an entire growing season (Wang, 1960). Even moderately high temperatures inhibit a number of reproductive processes in tomato and other species, resulting in poor fertilization and fruit set [reviewed in Snider and Oosterhuis (2011); Zinn et al. (2010)]. Because fruits are typically the consumed portion of most food crops (i.e., grain and horticultural crops), moderately elevated temperatures may result in disproportionately large yield reductions for major food crops relative to non-food crops with vegetative structures of economic importance (Snider and Oosterhuis, 2011). Consequently, a number of authors have reported that the moderately elevated air temperature increases projected to result from global climate change could negatively affect food-crop yields (Peng et al., 2004) and global food security (Lobell et al., 2008; Schmidhuber and Tubiello, 2007). Given the pronounced effect of above-optimal temperatures on crop yields, the rate of $\mathrm{HU}$ accumulation should also be considered when estimating crop yield responses to accumulated $\mathrm{HU}$.

It was hypothesized that moderate elevations in mean temperature would result in significant declines in estimated fresh tomato yields in eastern Oklahoma, thereby increasing the acreage needed to meet local consumption demands. The objectives of the current study were 1) to use variety trial data to identify a tomato cultivar producing maximal yields under southeastern Oklahoma conditions; 2) to perform multivariate response surface analysis to quantify how key management practices 
(i.e., planting date and growing season duration) and environmental parameters (i.e., accumulated HU during the growing season and rate of $\mathrm{HU}$ accumulation) interact to influence tomato production in southeastern Oklahoma; 3 ) to use the response surface model derived from Objective 2 to estimate marketable yields for a 20-year period (1990 to 2010) under actual and elevated air temperature scenarios; and 4) to use the 20-year yield estimates to quantify the amount of land in Atoka County (a sparsely populated eastern Oklahoma County) required to meet the combined consumption demands of that county and Oklahoma County (a heavily populated Oklahoma county) under different air temperature scenarios.

\section{Materials and Methods}

To evaluate effects of cultivar, management practices, and environmental factors on tomato production in southeast Oklahoma, data from experiments conducted from 1987 to 1992 were collected from the USDA-ARS Wes Watkins Agricultural Research Laboratory, Lane, OK (lat. 34 $17^{\prime} 17^{\prime \prime} \mathrm{N}$, long. $95^{\circ} 57^{\prime} 49^{\prime \prime} \mathrm{W}$ ) in Atoka County. The soil at Lane, OK, is classified as a Bernow fineloamy, siliceous, thermic Glossic Paleudalf. Data were collected only for plots where tomato seedlings $(\approx 6$ weeks past emergence) were transplanted in beds at a $1.83 \mathrm{~m}$ interrow spacing and $0.46-\mathrm{m}$ between-plant spacing. All plots used in this study were fertilized according to soil test recommendations to supply $112 \mathrm{~N}-54 \mathrm{P}-325 \mathrm{~K} \mathrm{~kg} \cdot \mathrm{ha}^{-1}$ and were drip-irrigated. All pest control and disease management practices were carried out using best management practices for the region. A minimum of five tomato plants per plot were harvested for yield estimates. All fruit weights and yield estimates were reported on a fresh weight (FW) basis.

Variety trials were conducted over 3 years (1987, 1988, and 1989) in southeastern Oklahoma to evaluate the impact of cultivar on tomato production. In 1987 the cvs. All Star, Big Set, Bingo, Carnival, Celebrity, Duke, Flash, Floramerica, Freedom, Independence, Jackpot, Jet Star, Liberty, Mountain Pride, Pacific, Pik Red, Revolution, Spring Giant, Step 688, Step 689, Summer Flavor 5000, Summer Flavor 6000, Sunny, Valerie, Willhite 101 , and Willhite 202 were evaluated for total and marketable fruit production ( $\left.\mathrm{FW} ; \mathrm{Mg} \cdot \mathrm{ha}^{-1}\right)$, percent marketable yield, fruit number/acre, and average fruit size $(\mathrm{kg})$. In 1988, the same parameters were evaluated using the following cultivars: All Star, Big Set, Carnival, Celebrity, Floradade, Jet Star, Liberty, Mountain Pride, Pacific, Step 688, Step 702, Summer Flavor 5000, Summer Flavor 6000, Sunny, and Whirlaway. In 1989, cultivars All Star, Carnival, Celebrity, Floradade, Mountain Pride, Pacific, Solar Set, Step 702, Step 709, Summer Flavor 5000, Sunny, and Willhite 101 were evaluated. The tomato cultivar consistently producing the most yields of marketable fruit in all 3 trial years was used for subsequent analysis of management and environmental effects on marketable tomato yield from 1987 to 1992.
To evaluate the impact of management strategies and environmental factors on tomato production in southeastern Oklahoma, 6 years of tomato productivity data encompassing 15 different transplant dates and 78 replicate plots for cv. Sunny from 1987 to 1992 were obtained from field experiments conducted at Lane, OK. Only data obtained from drip-irrigated plots receiving recommended fertilization rates were used for modeling. Response surface analysis was used to develop models that quantitatively defined impacts of management practices and environmental factors on marketable fruit yield in tomato. A single plot during a given growing season (i.e., transplant date) represented the experimental unit.

The response surface model is a form of multiple, non-linear regression that uses a combination of linear and quadratic terms and cross-products of linear terms to describe the interactive effects of multiple independent variables on a single dependent (response) variable (Freund et al., 2003). In this experiment, marketable fruit yield $\left(\mathrm{Mg} \cdot \mathrm{ha}^{-1}\right)$ served as the response variable. Management factors common in all experiments were the day of year (DOY) when transplanting occurred and growing season duration in days, and these two factors were used in the response surface analysis of management effects on marketable tomato production to estimate planting date and growing season duration required for maximal productivity. Planting dates used for regression analysis ranged from 12 Apr. $(\mathrm{DOY}=102)$ to 15 July $(\mathrm{DOY}=197)$, and growing season durations ranged from 72 to $123 \mathrm{~d}$.

To assess effects of prevailing environmental conditions during the growing season on marketable tomato production, climate

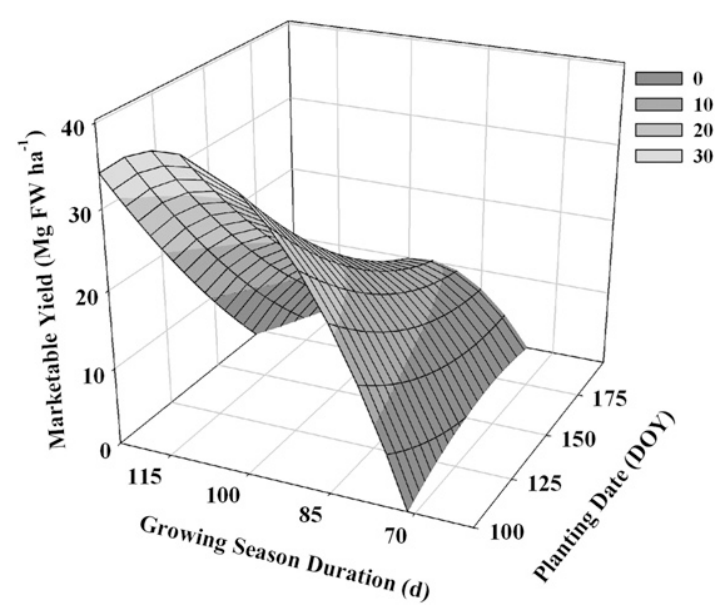

Fig. 1. A three-dimensional response surface profile plot with marketable yield as the response variable and transplant date and growing season duration as independent variables. Marketable yield is reported on a fresh weight (FW) basis. Different levels of shading in the figure legend represent marketable yield levels in $10 \mathrm{Mg} \mathrm{FW} /$ ha increments. The response surface model is based on marketable yield data derived from 78 replicate plots from 15 different plantings and sampled from 1987 to 1992 at Lane, OK $\left(P<0.0001 ; r^{2}=0.51\right)$

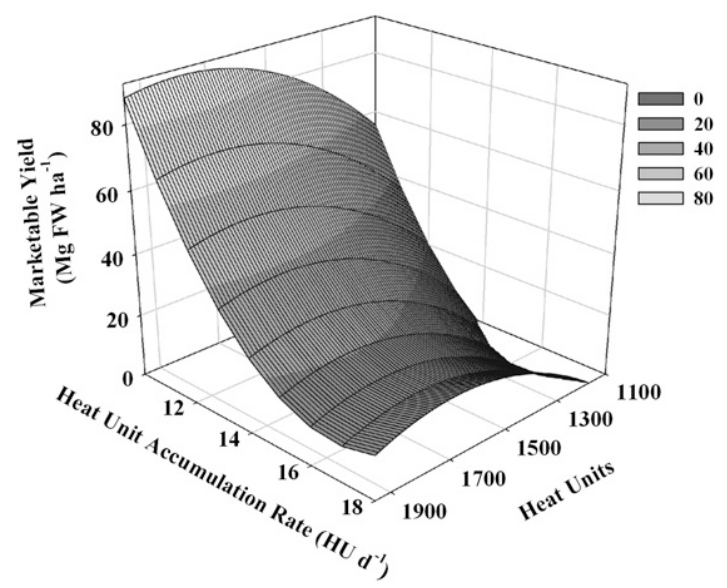

Fig. 2. A three-dimensional response surface profile plot with marketable yield as the response variable and accumulated heat units and heat unit accumulation rate (heat units per day) as the independent variables. Different levels of shading in the figure legend represent marketable yield levels in $20 \mathrm{Mg}$ fresh weight $(\mathrm{FW}) /$ ha increments. Marketable yield is reported on a FW basis. The response surface model is based on marketable yield data derived from 78 replicate plots from 15 different plantings sampled from 1987 to 1992 at Lane, OK $\left(P<0.0001 ; r^{2}=0.35\right)$. 
data were collected from the nearest COOP weather station located $\approx 5.6$ miles from the study site (McGee Creek Dam; lat. $34^{\circ} 18^{\prime} 36^{\prime \prime} \mathrm{N}$, long. $95^{\circ} 52^{\prime} 12^{\prime \prime} \mathrm{W}$ ). Daily precipitation, maximum daily temperature $\left(\mathrm{T}_{\max }\right)$, and minimum daily temperature $\left(\mathrm{T}_{\mathrm{min}}\right)$ were recorded for each growing season. Preliminary analysis showed that cumulative precipitation during the growing season did not significantly influence marketable tomato production (data not shown), likely as a result of effective drip irrigation management. $\mathrm{Cu}$ mulative HUs (growing degree-days) were calculated from daily $\mathrm{T}_{\max }$ and $\mathrm{T}_{\min }$ data for each growing season using a base temperature of $10{ }^{\circ} \mathrm{C}$ (Ortiz et al., 2007; Scholberg et al., 2000). Heat unit accumulation rate was calculated as: $\mathrm{HU} \div$ number of days in growing season. A two-factor response surface model was used to quantify interactive effects of HU and HU accumulation rate $(\mathrm{HU} / \mathrm{d})$ on marketable tomato production for Lane, OK.

Using the planting date and growing season duration shown to provide maximum productivity within the range of data (Fig. 1), $\mathrm{T}_{\max }$ and $\mathrm{T}_{\min }$ data obtained from McGee Creek Dam from 1990 to 2010 were used to determine marketable tomato yields based on the $\mathrm{HU} \times \mathrm{HU} / \mathrm{d}$ response surface model
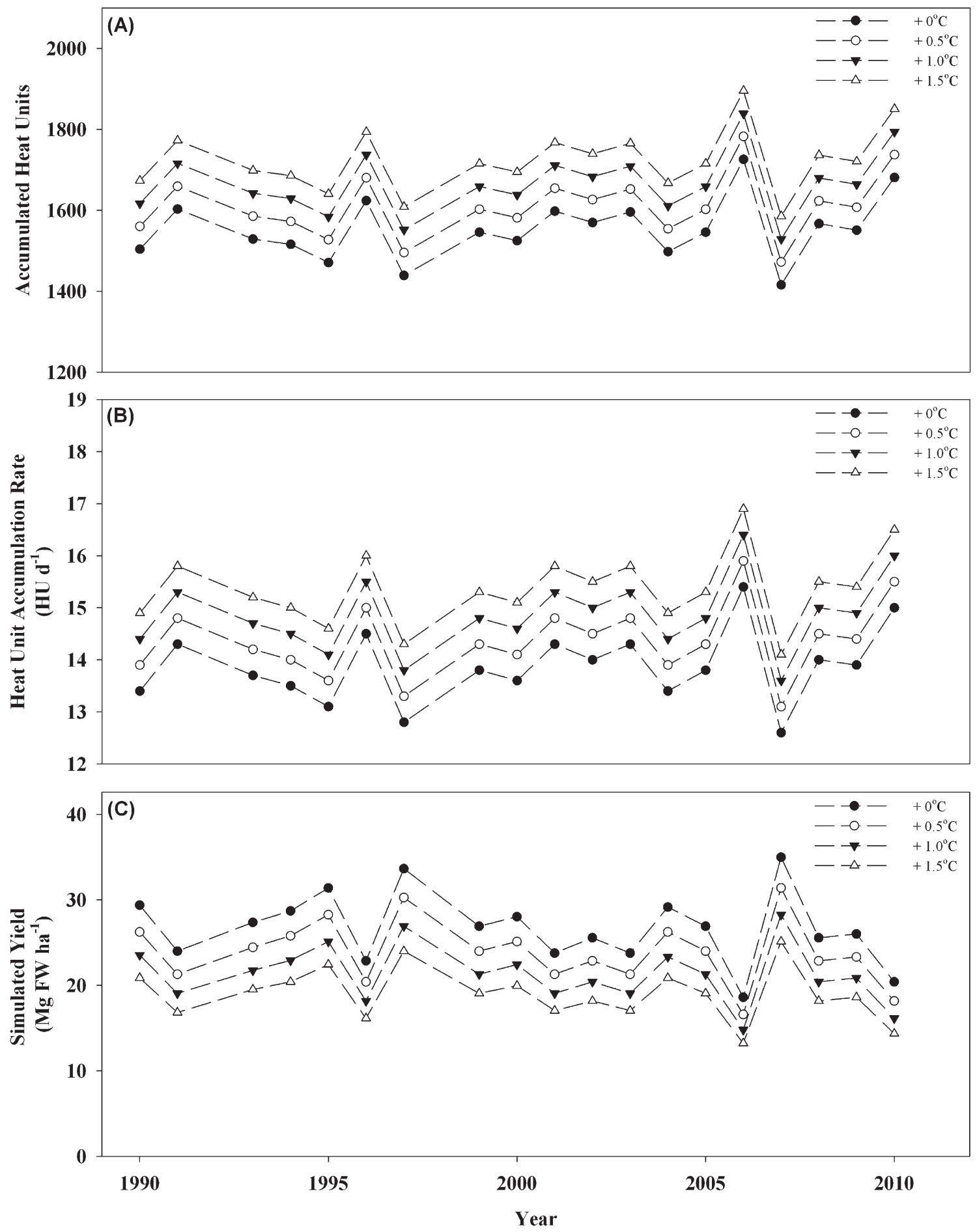

Fig. 3. Yearly tomato yield predictions from 1990 to 2010, assuming an optimal planting date (12 Apr.) and growing season length (112 d). Using a response surface function to evaluate interactive effects of heat units accumulated during the growing season and rate of heat unit accumulation, marketable yield [on a fresh weight (FW) basis] was predicted for four possible mean temperature scenarios: actual temperatures observed during the growing season (closed circles; +0) and mean temperature increases of $0.5^{\circ} \mathrm{C}$ (open circles; +0.5 ), $1.0^{\circ} \mathrm{C}$ (filled triangles; +1.0 ), and $1.5^{\circ} \mathrm{C}($ open triangles; +1.5 ). 
(Fig. 2). From the $\mathrm{HU} \times \mathrm{HU} / \mathrm{d}$ response surface model, estimated yields were reported for simulated temperature increases of $0.5,1.0$, and $1.5^{\circ} \mathrm{C}$. Simulated yields were reported on a yearly basis from 1990 to 2010 (Fig. 3) and as an average from 1990 to 2010 (Fig. 4); fresh marketable yields were expressed in $\mathrm{Mg} \cdot \mathrm{ha}^{-1}$. Although it is well established that time to maturity (growing season duration) is also influenced by HU accumulation, the optimal growing season duration derived from the response surface model was used to provide a uniform number of days with which to simulate long-term yield responses to increased temperature.

Many different definitions of "local food" exist; however, local has often been used to describe food that is produced and consumed within state boundaries (Duram and Oberholtzer, 2010). A heavily populated, within-state location with relatively high fresh tomato consumption demands was used to estimate amounts of existing cropland that would need to be converted into tomato production to supply local demand. To this end, Oklahoma County, a heavily populated county that contains a major metropolitan area within the state, was selected as a potential market for fresh tomatoes produced in Atoka County. To estimate the maximum acreage required to meet Oklahoma County consumption demands without detracting from the fresh tomato needs of Atoka County, it was assumed that all fresh tomato consumption requirements for both counties would be met by the harvested cropland available in Atoka County as reported in the 2007 Census of Agriculture (National Agricultural Statistics Service, 2009b). Per-capita fresh tomato consumption in the United States in 2010 was $9.45 \mathrm{~kg}$ annually (Economic Research Service, 2011). Consumption requirements (in $\mathrm{Mg}$ ) were determined by multiplying the populations reported in the 2010 Census for both counties by $9.45 \div$ 1000. Long-term yield estimates from 1990 to 2010 (Fig. 4) and harvested cropland estimates for Atoka County from the 2007 Census of Agriculture (National Agricultural Statistics Service, 2009b) were used to estimate the acreage required to meet consumption demands and the percent of harvested cropland that would need to be used for fresh tomato production. Also, the acreages required to meet consumption demands under average air temperature increases of $0.5,1.0$, and $1.5{ }^{\circ} \mathrm{C}$ temperature increases were reported based on 1990 to 2010 yield estimates.

The effect of cultivar on marketable tomato yield, total yield, percent marketable yield, and average fruit size was evaluated for each variety trial experiment using one-way analysis of variance and conventional least significant difference post hoc analysis $(\alpha=$ 0.05 ) was used for mean separation. The same approach was used to compare simulated yields under different air temperature scenarios. The interactive effects of planting date and growing season duration and the interactive effects of $\mathrm{HU}$ and $\mathrm{HU}$ accumulation rate were quantified using two-factor quadratic response surface models (Freund et al., 2003). All statistical analyses were performed using JMP Version 9.1 software (SAS Institute, Cary, NC).

\section{Results and Discussion}

Cultivar affected marketable fruit yield, total fruit yield, percent marketable yield, and average fruit size (Tables 1 and $2 ; P<0.0001$ for all parameters measured) in 1987 and 1988 but not in $1989[P=0.1126,0.2001$, 0.9121 , and 0.2841 for marketable fruit yield (avg. $30.78 \mathrm{Mg} \cdot \mathrm{ha}^{-1}$ ), total fruit yield (avg. $49.95 \mathrm{Mg} \cdot \mathrm{ha}^{-1}$ ), percent marketable yield (avg. 61.55\%), and average fruit weight (avg. $0.17 \mathrm{~kg} /$ fruit), respectively]. In 1987 (Table 1), cv. Carnival produced higher marketable yields than 17 of the entries and similar yields to eight of the entries. This cultivar had higher total yields than 19 entries and similar yields to six entries. 'Mountain Pride', 'All Star', and 'Liberty' had higher percent marketable yield than seven entries and similar percent marketable yields to 14 entries. 'Carnival' had greater average fruit weight than all but 'Willhite 202'. In 1988

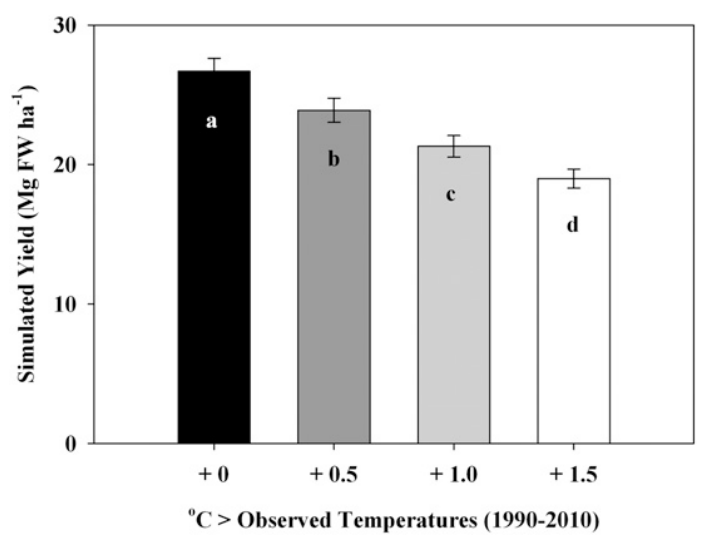

Fig. 4. Average marketable tomato yield predictions based on temperature data collected from 1990 to 2010 in Atoka County, OK, assuming an optimal planting date (12 Apr.) and growing season length (112 d). Average yield [on a fresh weight (FW) basis] was predicted for four possible mean temperature scenarios: actual temperatures observed during the growing seasons from 1990 to $2010(+0), 1990$ to 2010 average temperatures $+0.5^{\circ} \mathrm{C}(+0.5), 1990$ to 2010 average temperatures $+1.0{ }^{\circ} \mathrm{C}(+1.0)$, and 1990 to 2010 average temperatures $+1.5^{\circ} \mathrm{C}(+1.5)$.

Table 1. Effect of cultivar on tomato marketable yield, total yield, percent marketable yield, and average fruit size in $1987 .^{z}$

\begin{tabular}{|c|c|c|c|c|}
\hline Cultivar & $\begin{array}{c}\text { Marketable } \\
\text { yield (Mg FW/ha) }\end{array}$ & $\begin{array}{l}\text { Total yield } \\
(\mathrm{Mg} \mathrm{FW} / \mathrm{ha})\end{array}$ & $\begin{array}{l}\text { Marketable } \\
\text { yield }(\%)\end{array}$ & $\begin{array}{c}\text { Avg fruit } \\
\text { wt (kg/fruit) }\end{array}$ \\
\hline Carnival & $36.2 \pm 2.17^{\mathrm{A}}$ & $41.7 \pm 2.40^{\mathrm{A}}$ & $86.9 \pm 1.67^{\mathrm{AB}}$ & $0.25 \pm 0.007^{\mathrm{A}}$ \\
\hline Sunny & $33.8 \pm 1.83^{\mathrm{AB}}$ & $39.0 \pm 1.86^{\mathrm{AB}}$ & $86.5 \pm 1.46^{\mathrm{ABC}}$ & $0.19 \pm 0.005^{\mathrm{HIJKL}}$ \\
\hline Willhite 101 & $32.7 \pm 2.17^{\mathrm{AB}}$ & $38.7 \pm 2.24^{\mathrm{AB}}$ & $84.4 \pm 2.71^{\mathrm{ABCD}}$ & $0.22 \pm 0.007^{\mathrm{CDEF}}$ \\
\hline Pacific & $32.0 \pm 2.64^{\mathrm{ABC}}$ & $38.3 \pm 2.49^{\mathrm{AB}}$ & $83.5 \pm 3.64^{\mathrm{ABCD}}$ & $0.23 \pm 0.01^{\mathrm{CD}}$ \\
\hline Summer Flavor 5000 & $30.8 \pm 2.28^{\mathrm{ABCD}}$ & $36.4 \pm 2.53^{\mathrm{ABC}}$ & $84.6 \pm 2.19^{\mathrm{ABCD}}$ & $0.22 \pm 0.002^{\mathrm{CDEF}}$ \\
\hline Mountain Pride & $30.7 \pm 1.75^{\mathrm{ABCD}}$ & $34.4 \pm 1.72^{\mathrm{BCDE}}$ & $89.1 \pm 0.95^{\mathrm{A}}$ & $0.18 \pm 0.005^{\mathrm{IJKL}}$ \\
\hline All Star & $30.7 \pm 1.88^{\mathrm{ABCD}}$ & $34.5 \pm 1.99^{\mathrm{BCDE}}$ & $89.1 \pm 1.95^{\mathrm{A}}$ & $0.19 \pm 0.005^{\mathrm{GHI}}$ \\
\hline Liberty & $30.3 \pm 1.88^{\mathrm{ABCDE}}$ & $34.0 \pm 1.81^{\mathrm{BCDEF}}$ & $89.1 \pm 2.77^{\mathrm{A}}$ & $0.18 \pm 0.004^{\mathrm{JKL}}$ \\
\hline Celebrity & $30.2 \pm 2.44^{\mathrm{ABCDE}}$ & $36.4 \pm 3.25^{\mathrm{ABC}}$ & $83.6 \pm 2.51^{\mathrm{ABCD}}$ & $0.22 \pm 0.007^{\mathrm{CDE}}$ \\
\hline Willhite 202 & $30.0 \pm 2.78^{\mathrm{BCDEF}}$ & $38.9 \pm 2.91^{\mathrm{AB}}$ & $76.5 \pm 2.53^{\mathrm{DEFG}}$ & $0.25 \pm 0.006^{\mathrm{AB}}$ \\
\hline Step 688 & $29.7 \pm 1.97^{\mathrm{BCDEFG}}$ & $35.2 \pm 2.24^{\mathrm{BCD}}$ & $84.4 \pm 1.37^{\mathrm{ABCD}}$ & $0.19 \pm 0.005^{\mathrm{HIJK}}$ \\
\hline Summer Flavor 6000 & $29.1 \pm 2.13^{\mathrm{BCDEFG}}$ & $34.7 \pm 1.99^{\mathrm{BCD}}$ & $83.4 \pm 2.24^{\mathrm{ABCD}}$ & $0.21 \pm 0.008^{\mathrm{EF}}$ \\
\hline Bingo & $26.6 \pm 2.10^{\mathrm{CDEFGH}}$ & $31.1 \pm 2.35^{\mathrm{CDEFG}}$ & $85.9 \pm 2.32^{\mathrm{ABC}}$ & $0.22 \pm 0.009^{\mathrm{CDE}}$ \\
\hline Independence & $25.9 \pm 1.46^{\mathrm{DEFGH}}$ & $31.6 \pm 1.12^{\mathrm{CDEFG}}$ & $81.8 \pm 2.02^{\mathrm{ABCDE}}$ & $0.19 \pm 0.005^{\mathrm{HIJK}}$ \\
\hline Valerie & $25.7 \pm 2.10^{\mathrm{DEFGH}}$ & $29.4 \pm 1.93^{\mathrm{DEFG}}$ & $87.2 \pm 3.62^{\mathrm{AB}}$ & $0.19 \pm 0.005^{\mathrm{HIJ}}$ \\
\hline Flash & $24.6 \pm 1.64^{\mathrm{EFGHI}}$ & $30.1 \pm 2.20^{\mathrm{CDEFG}}$ & $82.3 \pm 2.02^{\mathrm{ABCDE}}$ & $0.18 \pm 0.004^{\mathrm{IJKL}}$ \\
\hline Freedom & $24.6 \pm 2.40^{\mathrm{EFGHI}}$ & $30.3 \pm 2.20^{\mathrm{CDEFG}}$ & $80.3 \pm 3.54^{\mathrm{BCDE}}$ & $0.21 \pm 0.005^{\mathrm{EFG}}$ \\
\hline Step 689 & $24.2 \pm 1.64^{\mathrm{FGHI}}$ & $27.2 \pm 1.61^{\mathrm{G}}$ & $89.2 \pm 2.51^{\mathrm{A}}$ & $0.18 \pm 0.005^{\mathrm{IJKL}}$ \\
\hline Pik Red & $24.0 \pm 2.35^{\mathrm{GHI}}$ & $28.9 \pm 2.60^{\mathrm{DEFG}}$ & $83.0 \pm 2.66^{\mathrm{ABCD}}$ & $0.21 \pm 0.005^{\mathrm{EF}}$ \\
\hline Jet Star & $24.0 \pm 2.49^{\mathrm{GHI}}$ & $30.2 \pm 3.16^{\mathrm{CDEFG}}$ & $79.1 \pm 3.04^{\mathrm{BCDEF}}$ & $0.20 \pm 0.005^{\mathrm{FGH}}$ \\
\hline Big Set & $23.7 \pm 2.35^{\mathrm{GHI}}$ & $31.7 \pm 2.33^{\mathrm{CDEFG}}$ & $74.3 \pm 4.39^{\mathrm{EFGH}}$ & $0.18 \pm 0.005^{\mathrm{IJKL}}$ \\
\hline Duke & $22.0 \pm 1.19^{\mathrm{HI}}$ & $28.1 \pm 1.41^{\mathrm{EFG}}$ & $78.5 \pm 2.94^{\mathrm{CDEF}}$ & $0.21 \pm 0.005^{\mathrm{DEF}}$ \\
\hline Floramerica & $19.1 \pm 1.90^{\mathrm{IJ}}$ & $27.6 \pm 1.77^{\mathrm{G}}$ & $69.0 \pm 4.54^{\mathrm{GH}}$ & $0.23 \pm 0.007^{\mathrm{BC}}$ \\
\hline Spring Giant & $19.0 \pm 1.79^{\mathrm{IJ}}$ & $27.8 \pm 2.31^{\mathrm{FG}}$ & $68.4 \pm 3.64^{\mathrm{H}}$ & $0.17 \pm 0.008^{\mathrm{L}}$ \\
\hline Jackpot & $15.8 \pm 3.63^{\mathrm{J}}$ & $20.5 \pm 3.63^{\mathrm{H}}$ & $72.2 \pm 5.21^{\mathrm{FGH}}$ & $0.19 \pm 0.005^{\mathrm{HIJKL}}$ \\
\hline \multirow[t]{2}{*}{ Revolution } & $15.8 \pm 1.28^{\mathrm{J}}$ & $19.9 \pm 1.66^{\mathrm{H}}$ & $79.8 \pm 2.59^{\mathrm{BCDEF}}$ & $0.18 \pm 0.003^{\mathrm{KL}}$ \\
\hline & $P<0.0001$ & $P<0.0001$ & $P<0.0001$ & $P<0.0001$ \\
\hline
\end{tabular}

${ }^{\mathrm{z}}$ All data are reported on a fresh weight $(\mathrm{FW})$ basis. Values are means $\pm \mathrm{SE}(\mathrm{n}=8)$; values not sharing a common letter within a column are significantly different (least significant difference; $P<0.05$ ). 
Table 2. Effect of cultivar on tomato marketable yield, total yield, percent marketable yield, and average fruit size in $1988 .^{z}$

\begin{tabular}{lcccc}
\hline Cultivar & $\begin{array}{c}\text { Marketable } \\
\text { yield (Mg FW/ha) }\end{array}$ & $\begin{array}{c}\text { Total yield } \\
(\mathrm{Mg} \mathrm{FW} / \mathrm{ha})\end{array}$ & $\begin{array}{c}\text { Marketable } \\
\text { yield }(\%)\end{array}$ & $\begin{array}{c}\text { Avg fruit } \\
\text { wt (kg/fruit) }\end{array}$ \\
Step 688 & $18.3 \pm 1.93^{\mathrm{A}}$ & $58.9 \pm 3.97^{\mathrm{ABC}}$ & $30.9 \pm 2.04^{\mathrm{A}}$ & $0.15 \pm 0.005^{\mathrm{ABC}}$ \\
Mountain Pride & $17.3 \pm 1.79^{\mathrm{AB}}$ & $55.0 \pm 3.20^{\mathrm{ABC}}$ & $31.5 \pm 2.87^{\mathrm{A}}$ & $0.15 \pm 0.007^{\mathrm{ABC}}$ \\
Sunny & $16.4 \pm 0.74^{\mathrm{ABC}}$ & $55.0 \pm 1.08^{\mathrm{ABC}}$ & $29.9 \pm 1.58^{\mathrm{A}}$ & $0.17 \pm 0.006^{\mathrm{A}}$ \\
All Star & $14.6 \pm 0.83^{\mathrm{BC}}$ & $51.6 \pm 3.05^{\mathrm{CDE}}$ & $28.7 \pm 1.83^{\mathrm{AB}}$ & $0.15 \pm 0.005^{\mathrm{ABC}}$ \\
Step 702 & $13.6 \pm 1.48^{\mathrm{CD}}$ & $56.8 \pm 1.10^{\mathrm{ABC}}$ & $23.9 \pm 2.56^{\mathrm{BC}}$ & $0.10 \pm 0.002^{\mathrm{G}}$ \\
Jet Star & $11.0 \pm 1.48^{\mathrm{DE}}$ & $45.3 \pm 1.55^{\mathrm{E}}$ & $24.0 \pm 3.07^{\mathrm{BC}}$ & $0.15 \pm 0.004^{\mathrm{BCD}}$ \\
Floradade & $10.6 \pm 1.70^{\mathrm{DE}}$ & $52.4 \pm 2.62^{\mathrm{BCDE}}$ & $19.6 \pm 2.52^{\mathrm{CD}}$ & $0.15 \pm 0.005^{\mathrm{CDE}}$ \\
Summer Flavor 5000 & $7.7 \pm 0.92^{\mathrm{EF}}$ & $56.2 \pm 2.80^{\mathrm{ABC}}$ & $14.0 \pm 1.73^{\mathrm{DE}}$ & $0.12 \pm 0.005^{\mathrm{FG}}$ \\
Celebrity & $7.6 \pm 1.34^{\mathrm{EF}}$ & $59.6 \pm 3.27^{\mathrm{AB}}$ & $12.3 \pm 1.78^{\mathrm{E}}$ & $0.13 \pm 0.008^{\mathrm{EF}}$ \\
Carnival & $7.5 \pm 0.99^{\mathrm{EF}}$ & $60.9 \pm 3.29^{\mathrm{A}}$ & $12.3 \pm 1.51^{\mathrm{E}}$ & $0.13 \pm 0.007^{\mathrm{DEF}}$ \\
Big Set & $6.5 \pm 1.12^{\mathrm{F}}$ & $54.8 \pm 2.20^{\mathrm{ABC}}$ & $11.9 \pm 1.98^{\mathrm{E}}$ & $0.16 \pm 0.006^{\mathrm{ABC}}$ \\
Liberty & $6.3 \pm 0.99^{\mathrm{F}}$ & $46.4 \pm 1.41^{\mathrm{DE}}$ & $13.5 \pm 1.62^{\mathrm{E}}$ & $0.10 \pm 0.004^{\mathrm{G}}$ \\
Summer Flavor 6000 & $5.8 \pm 0.36^{\mathrm{F}}$ & $53.4 \pm 2.71^{\mathrm{ABCD}}$ & $11.1 \pm 0.93^{\mathrm{E}}$ & $0.14 \pm 0.008^{\mathrm{CDE}}$ \\
Pacific & $5.3 \pm 1.10^{\mathrm{F}}$ & $54.3 \pm 2.60^{\mathrm{ABC}}$ & $9.8 \pm 2.19^{\mathrm{E}}$ & $0.16 \pm 0.009^{\mathrm{AB}}$ \\
Whirlaway & $4.9 \pm 0.99^{\mathrm{F}}$ & $46.0 \pm 3.65^{\mathrm{DE}}$ & $10.3 \pm 1.64^{\mathrm{E}}$ & $0.10 \pm 0.008^{\mathrm{G}}$ \\
& $P<0.0001$ & $P<0.0001$ & $P<0.0001$ & $P<0.0001$ \\
\hline
\end{tabular}

${ }^{\mathrm{z}} \mathrm{All}$ data are reported on a fresh weight $(\mathrm{FW})$ basis. Values are means $\pm \mathrm{SE}(\mathrm{n}=8)$; values not sharing a common letter within a column are significantly different (least significant difference; $P<0.05$ ).

(Table 2), cv. Step 688 had higher marketable yield than 12 entries and was similar to two entries. 'Carnival' had a total yield higher than five entries and was similar to nine entries. 'Step 688', 'Mountain Pride', and 'Sunny' had a percent marketable yield higher than 11 entries and were similar to one entry. 'Sunny' had an average fruit weight greater than nine entries and similar to five entries. Several of the tomato cultivars in these trials are currently recommended for commercial production by the Oklahoma Cooperative Extension Service (McGraw et al., 2007) and appear to be well suited for marketable tomato production under southeastern Oklahoma conditions.

Marketable yield was significantly affected by planting date and growing season duration $\left(P<0.0001 ; r^{2}=0.51\right.$; Fig. 1$)$. Successively earlier planting dates produced higher marketable yields, where the earliest planting date (12 Apr.; DOY = 102) used in this study produced the highest marketable yields (Fig. 1). Although the response surface model predicts increased yields with earlier planting dates, it is important to note that transplanting should occur after the last frost of the season to avoid plant injury and subsequent yield losses (McGraw et al., 2007). The date of $12 \mathrm{Apr}$. is considered the latest date in the spring for which $0{ }^{\circ} \mathrm{C}$ weather can be expected for Atoka County (Natural Resource Conservation Service, 2007). For crops planted on 12 Apr., the optimal growing season length for maximum marketable tomato yields was 112 d (Fig. 1). Marketable yield was also significantly affected by HU and HU accumulation rate $\left(P<0.0001 ; r^{2}=0.35\right.$; Fig. 2$)$. Increased HU accumulation rate resulted in negative effects on marketable yield. The highest marketable yields at each HU accumulation rate ranged from $49.59 \mathrm{Mg} \cdot \mathrm{ha}^{-1}$ at 12.15 $\mathrm{HU} / \mathrm{d}$ to $17.07 \mathrm{Mg} \cdot \mathrm{ha}^{-1}$ at $17.35 \mathrm{HU} / \mathrm{d}$ (Fig. 2). At the lowest HU accumulation rate observed (12.15 HU/d), the optimal number of HU accumulated during the growing season for maximum yield was 1755 . Scholberg et al. (2000) reported a positive, linear response of tomato fruit dry matter production to $\mathrm{HU}$ for the tomato cv. Sunny grown under various irrigation regimes in Florida. However, in those experiments, HU did not exceed 1400, whereas the maximum HU accumulation for a single growing season in the present study was 1907. It should be noted that some investigators have used different base temperatures for HU calculations than those used in the present study (Perry et al., 1997). However, a different base temperature would not change the final trend; only the absolute HU values would change. The results (Fig. 2) indicate that using $\mathrm{HU}$ alone to predict tomato yields is likely an oversimplification because $\mathrm{HU}$ accumulation rate also had a pronounced affect on marketable tomato yield.

Using the optimal planting date (12 Apr.) and growing season duration (112 d), the number of HU accumulated during the growing season and $\mathrm{HU}$ accumulation rate were determined for a 20-year period based on available data from McGee Creek Dam (Fig. $3 \mathrm{~A}-\mathrm{B})$. Using the $\mathrm{HU} \times \mathrm{HU}$ accumulation rate model (Fig. 2), marketable tomato yields were estimated on a yearly basis under actual temperature conditions and under 0.5, 1.0, and $1.5{ }^{\circ} \mathrm{C}$ simulated increases in average temperature (Fig. 3C). In all years for which temperature data were available, increasing mean temperature resulted in lower estimated marketable tomato yields (Fig. 3C). Average yields estimated from 1990 to 2010 were significantly affected by simulated temperature increases (Fig. 4). Marketable tomato yields declined by $10.5 \%, 20.2 \%$, and $28.8 \%$ under $0.5,1.0$, and $1.5{ }^{\circ} \mathrm{C}$ temperature increases, respectively, relative to actual temperature conditions from 1990 to 2010 (Fig. 4). Because the simulated yields under different temperature conditions are based on a regression model calibrated to real yield data from 15 different transplant dates across 6 years, we emphasize that the aforementioned data (Fig. 4) provide realistic estimates of marketable yield losses with increased temperature for field-grown tomato. The $\approx 20 \%$ decline in yield per degree Celsius increase in daily maximum temperature illustrates the exceptional sensitivity of tomato to increased temperature as the projected yield losses per degree Celsius increase are substantially higher than those predicted for other crop species (Peng et al., 2004).

These findings indicate that above-optimal temperature is already a limitation to potential yields in eastern Oklahoma and that further increases in mean temperature would result in substantial yield reductions. The predicted marketable yield based on 1990 to 2010 weather data (26.66 Mg.ha- ${ }^{-1}$; Fig. 4) is substantially lower than yields that could be achieved under low rates of heat unit accumulation (Fig. 2). A $27{ }^{\circ} \mathrm{C}$ daily maximum temperature is considered optimal for tomato growth and development (Perry et al., 1997), whereas the average daily maximum temperature for Atoka County from 1990 to 2010 is well above the optimum $\left(\mathrm{T}_{\max }=29.9^{\circ} \mathrm{C}\right)$. As a result of the exceptional thermosensitivity of key reproductive processes (i.e., gametophyte development and in vivo fertilization; Snider and Oosterhuis, 2011; Zinn et al., 2010), moderately elevated temperature has been shown to decrease fruit set in tomato (Sato et al., 2000) and to substantially limit yields of other crops with economically valuable reproductive structures under elevated temperature conditions (Peng et al., 2004). Peng et al. (2004) estimated that every $1-^{\circ} \mathrm{C}$ increase in growing season minimum temperature resulting from global warming would result in a $10 \%$ decline in rice yields. Elevated atmospheric $\mathrm{CO}_{2}$ levels, projected to result from global climate change, are expected to have largely positive impacts on crop productivity (Schmidhuber and Tubiello, 2007) and could potentially help mitigate temperature-related yield reductions (Fig. 4). However, marketable yield reductions predicted for only a $1.5-^{\circ} \mathrm{C}$ average temperature increase (28.8\% decline; Fig. 4$)$ are larger than yield improvements expected through increased atmospheric $\mathrm{CO}_{2}$ levels $(10 \%$ to $20 \%$ increase for $\mathrm{C}_{3}$ plants under $550 \mathrm{ppm} \mathrm{CO}_{2}$; Schmidhuber and Tubiello, 2007). Although Figure 4 illustrates clearly the negative impact of increased temperature on marketable tomato yields, it should also be noted that the tomato crop might also be transplanted earlier under global climate change, which could potentially offset some of the yield losses predicted in the current study.

Atoka County, OK, contained 23,492 ha of harvested cropland in 2007 (National Agricultural Statistics Service, 2009b). Of that acreage, only $0.003 \%$ (Fig. $5 \mathrm{~A}$ ) or 0.81 ha (Fig. $5 \mathrm{~F}$ ) of the total harvested cropland in Atoka County was used for tomato production (National Agricultural Statistics Service, 2009b). Using the 1990 to 2010 average yield estimates; Fig. $4 ;+0{ }^{\circ} \mathrm{C}$ ) and assuming the combined consumption demands of Atoka and Oklahoma Counties would be met with the existing harvested cropland in Atoka County, $\approx 259$ ha of land (1.1\% of harvested cropland) would need to be converted into tomato production (Figs. 5B and 5F). Assuming mean temperature increases of $0.5,1.0$, and $1.5^{\circ} \mathrm{C}$, the amount of 

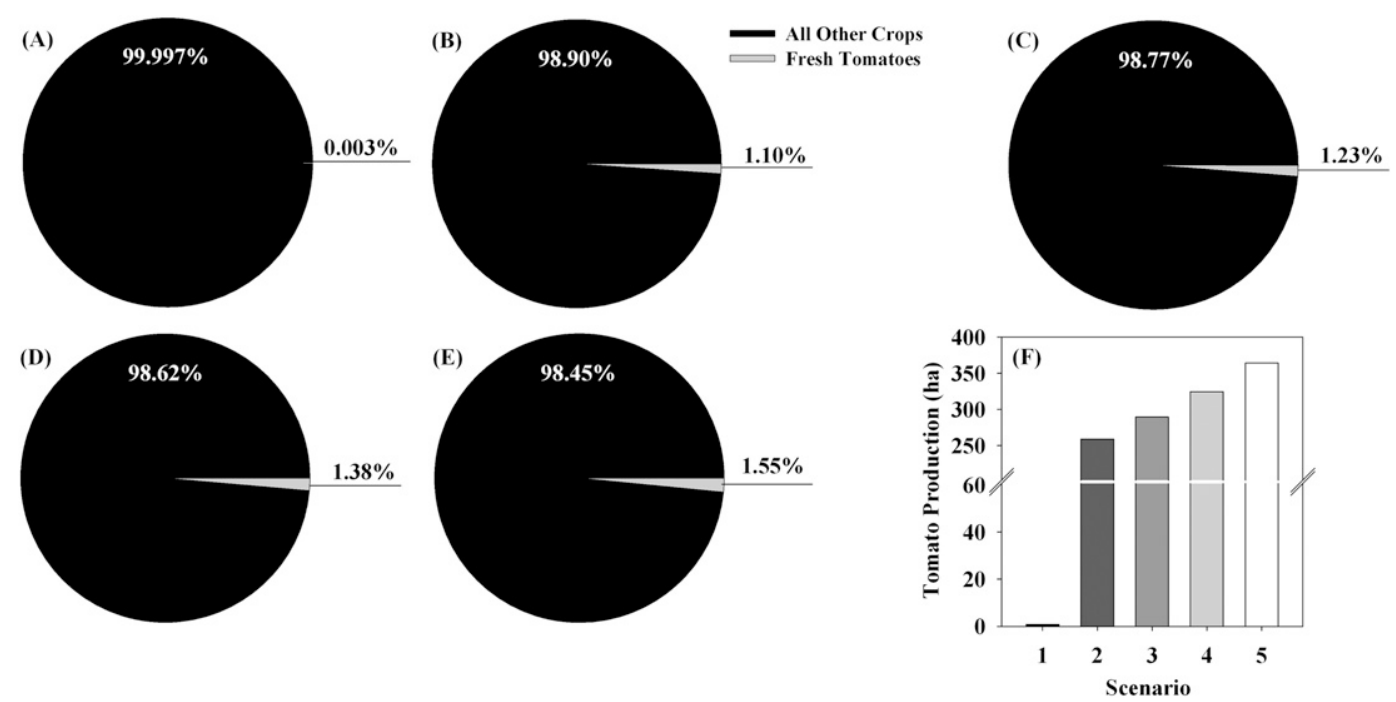

Fig. 5. Percent (A-E) and acreage (F) of harvested cropland in Atoka County, OK, used for fresh tomato production under five different scenarios: actual acreage used for tomato production in Atoka County according to the 2007 Census of Agriculture (A and F/Scenario 1), acreage required to meet the combined consumption demands of Atoka and Oklahoma Counties based on yield estimates using 1990 to 2010 average temperatures (B and F/Scenario 2), 1990 to 2010 average temperatures $+0.5^{\circ} \mathrm{C}(\mathbf{C}$ and $\mathbf{F} /$ Scenario 3$), 1990$ to 2010 average temperatures $+1.0^{\circ} \mathrm{C}(\mathbf{D}$ and $\mathbf{F} /$ Scenario 4$)$, and 1990 to 2010 average temperatures $+1.5^{\circ} \mathrm{C}(\mathbf{E}$ and $\mathbf{F} /$ Scenario 5$)$.

land needed to feed the same number of people would increase to 289,325 , and $364 \mathrm{ha}^{-1}$, respectively (Fig. 5F); this accounts for $1.23 \%, 1.38 \%$, and $1.55 \%$ of harvested cropland in Atoka County (Fig. 5C-E).

Crop productivity is largely governed by regional characteristics (Lobell et al., 2003). Consequently, estimates of local food production based on actual productivity data from long-term field experiments are of value in assessing local food production needs. Based on the data, two general statements can be made: 1) to meet local fresh tomato consumption demands, the land area dedicated to tomato production would need to be increased substantially in eastern Oklahoma; and 2) moderate increases in mean temperature would be expected to significantly increase the land area required to meet local food consumption demands by decreasing per-acre productivity. Although the land area required to meet consumption demands of Atoka and Oklahoma Counties represents a small percentage $(1.1 \%)$ of the total harvested cropland in Atoka County, tomato production, especially hand-harvested tomato production, is labor-intensive (McGraw et al., 2007) and would require a large manual labor force. Although this could be an obstacle to incorporating tomato production into existing agricultural systems, the demand for manual labor may positively affect the social component of agricultural sustainability through job creation (Feenstra, 2002).

The amount of land required to meet local fresh tomato consumption demand is predicted to increase under elevated temperature conditions as a result of decreased marketable yields in eastern Oklahoma (Fig. 5). By estimating changes in agricultural land value under a global warming scenario, Mendelsohn et al. (1994) reported that locations at more northern latitudes in the United States would experience a net increase in agricultural productivity, whereas southern states, including Oklahoma, would experience net declines in productivity under global warming. Mendelsohn et al. (1994) further suggested that net agricultural productivity in the United States would be positively affected by global warming, even in the absence of $\mathrm{CO}_{2}$ fertilization. Consequently, a number of researchers have focused on regions outside of the United States as key areas where food insecurity may be a major concern (e.g., Lobell et al., 2008; Schmidhuber and Tubiello, 2007). Because fresh-market tomatoes and other crops are currently grown under above-optimal temperature conditions in the southern United States, it is likely that increases in temperature may limit local food production (Fig. 4) in these regions even without concomitant declines in national food security (Mendelsohn et al., 1994).

\section{Literature Cited}

Blanke, M.M. and B. Burdick. 2005. Food (miles) for thought: Energy balance for locally-grown versus imported apple fruit. Environ. Sci. Pollution Res. 12:125-127.

DuPuis, M.E. and D. Goodman. 2005. Should we go home to eat? Toward a reflexive politics of localism. J. Rural Stud. 21:359-371.

Duram, L. and L. Oberholtzer. 2010. A geographic approach to place and natural resource use in local food systems. Renewable Agr. Food Systems 25:99-108.

Economic Research Service. 2009. Briefing roomsVegetables and melons: Tomatoes. 20 July 2011. $<$ http://www.ers.usda.gov/briefing/vegetables/ tomatoes.htm>.

Economic Research Service. 2011. Vegetables and melons yearbook data. 20 July 2011. <http://usda. mannlib.cornell.edu/usda/ers/89011/89011.pdf $>$.

Feenstra, G.W. 1997. Local food systems and sustainable communities. Amer. J. Sustainable Agr. 12:28-36.

Feenstra, G.W. 2002. Creating space for sustainable food systems: Lessons from the field. Agr. Human Values 19:99-106.
Freund, R., R. Littell, and L. Creighton. 2003. Regression using JMP ${ }^{\circledR}$. SAS Institute Inc., Cary, NC.

Gilmore, E.C. and J.S. Rogers. 1958. Heat units as a method of measuring maturity in $\operatorname{corn}^{1}$. Agron. J. 50:611-615.

Jones, A. 2002. An environmental assessment of food supply chains: A case study on dessert apples. Environ. Assessment 30:560-576.

Lapping, M.B. 2004. Toward the recovery of the local in the globalizing food system: The role of alternative agricultural and food models in the US. Ethics Place Environ. 7:141-150.

Lobell, D.B., G.P. Asner, J.L. Ortiz-Monasterio, and T.L. Benning. 2003. Remote sensing of regional crop production in the Yaqui Valley, Mexico: Estimates and uncertainties. Agr. Ecosyst. Environ. 94:205-220.

Lobell, D.B., M.B. Burke, C. Tebaldi, M.D. Mastrandrea, W.P. Falcon, and R.L. Naylor. 2008. Prioritizing climate change adaptation needs for food security in 2030. Science 319:607-610.

Lyson, T.A. and A. Guptill. 2004. Commodity agriculture, civic agriculture, and the future of U.S. farming. Rural Sociol. 69:370-385.

McGraw, D., J. Motes, and R.J. Schatzer. 2007. Commercial production of fresh market tomatoes. Oklahoma Cooperative Extension Service. HLA-6019.

Mendelsohn, R., W.D. Nordhaus, and D. Shaw. 1994. The impact of global warming on agriculture: A Ricardian analysis. Amer. Econ. Rev. 84:753-771.

National Agricultural Statistics Service. 2009a. 2007 Census of agriculture-Agricultural diversification. 20 July 2011. <http://www.agcensus. usda.gov/Publications/2007/Online_Highlights/ Fact_Sheets/agricultural_diversification.pdf $>$.

National Agricultural Statistics Service. 2009b. 2007 Census of agriculture - Oklahoma state and county data. 20 July $2011 .<\mathrm{http}: / /$ www.agcensus. usda.gov/Publications/2007/Full_Report/ Volume_1,_Chapter_2County_Level/OKklahoma/ okv1.pdf $>$.

Natural Resource Conservation Service. 2007. Supplement to the soil survey of Atoka County, Oklahoma. 20 July 2011. <http://soildatamart. nrcs.usda.gov/Manuscripts/OK005/0/Atok a.pdf>. 
Orlandi, F., B. Romano, and M. Fornaciari. 2005. Relationship between flowering and heat units to analyze crop efficiency of olive cultivars located in southern Italy. HortScience 40:64-68.

Ortiz, R., J. Crossa, M. Vargas, and J. Izquierdo. 2007. Studying the effect of environmental variables on the genotype $\times$ environment interaction of tomato. Euphytica 153:119-134.

Peng, S., J. Huang, J.E. Sheehy, R.C. Laza, R.M. Visperas, X. Zhong, G.S. Centeno, G.S. Khush, and K.G. Cassman. 2004. Rice yields decline with higher night temperature from global warming. Proc. Natl. Acad. Sci. USA 101:9971-9975.

Peng, S., D.R. Krieg, and S.K. Hicks. 1989. Cotton lint yield response to accumulated heat units and soil water supply. Field Crops Res. 19:253262.

Perry, K.B., Y. Wu, D.C. Sanders, J.T. Garrett, D.R. Decoteau, R.T. Nagata, R.J. Dufault, K.D. Batal, D.M. Granberry, and W.J. McLaurin. 1997. Heat units to predict tomato harvest in the southeast USA. Agr. For. Meteorol. 84:249-254.

Reeves, P.H. and G. Coupland. 2000. Response of plant development to environment: Control of flowering by daylength and temperature. Curr. Opin. Plant Biol. 3:37-42.

Russo, V.M. and B.W. Roberts. 1991. Variable yield of bell pepper established on converted perennial pasture fertilized according to recommendations. HortTechnology 1:39-41.

Sato, S., M.M. Peet, and J.F. Thomas. 2000. Physiological factors limit fruit set of tomato (Lycopersicon esculentum Mill.) under chronic, mild heat stress. Plant Cell Environ. 23:719-726.

Schmidhuber, J. and F.N. Tubiello. 2007. Global food security under climate change. Proc. Natl. Acad. Sci. USA 104:19703-19708.

Scholberg, J., B.L. McNeal, J.W. Jones, K.J. Boote, C.D. Stanley, and T.A. Obreza. 2000. Growth and canopy characteristics of field-grown tomato. Agron. J. 92:152-159.
Snider, J.L. and D.M. Oosterhuis. 2011. How does timing, duration, and severity of heat stress influence pollen-pistil interactions in angiosperms? Plant Signal. Behav. 6:930933.

Timmons, D., Q. Wang, and D. Lass. 2008. Local foods: Estimating capacity. J. Ext. 46:1-11.

Wallgren, C. 2006. Local or global food markets: A comparison of energy use for transport. Local Environ. 11:233-251.

Wang, J.Y. 1960. A critique of the heat unit approach to plant response studies. Ecology 41:785-790.

Weatherell, C., A. Tregear, and J. Allinson. 2003. In search of the concerned consumer: UK perceptions of food, farming, and buying local. J. Rural Stud. 19:233-244.

Zinn, K.E., M. Tunc-Ozdemir, and J.F. Harper. 2010. Temperature stress and plant sexual reproduction: Uncovering the weakest links. J. Expt. Bot. 61:1959-1968. 